\title{
ON THE MECHANISM OF PROTECTIVE ACTION OF COLD ACCLIMATIZATION AGAINST CARBON TETRACHLORIDE- AND ETHIONINE-INDUCED FATTY LIVER
}

\author{
AURA LOPEZ DE O.; C. A. CARMONA DE G. \& H. MOUSSATCHE $/{ }^{+}$
}

\begin{abstract}
Unidade de Investigación en Ciencias Funcionales, Escuela de Ciencias Veterinarias, Universidad Centro Occidental Lisandro Alvarado, Barquisimeto, Venezuela *Departamento de Fisiologia e Farmacodinamica, Instituto Oswaldo Cruz, Av. Brasil 4365, $21045-900$ Rio de Janeiro, RJ, Brasil
\end{abstract}

In this study the hepatic lipoprotein lipase (LPL) activity was evaluated in adull female mice acclimatized at $5^{\circ} \mathrm{C}$ and submitted to carbon tetrachloride $\left(\mathrm{CCl}_{4}\right)$ or ethionine, in order to determine the possible role of this enzyme in the fatty liver. The results were compared with those obtained in mice kept at room temperature $\left(27^{\circ} \mathrm{C}\right)$ that received the same hepatoesteatosis inducing agent. In contrast to animals kept at room temperature, in cold acclimatized mice neither the enhancement of the LPL-liver activity by the action of $\mathrm{CCl}_{4}$ or ethionine occurred nor the development of fatty infiltration in the liver was observed. We conclude that the low temperature induced a protective effect against $\mathrm{CCl}_{4}$ or ethionine-induced fatty liver that was correlated with the no-increase of the hepatic LPL activity.

Key words: cold acclimatization - hepatic lipoprotein lipase - fatty liver - carbon letrachloride - ethionine

The liver plays a central role in the synthesis and degradation of plasma lipoproteins, having specific receptors for remnant chylomicrons and low density lipoproteins (LDL) internalization (Brown \& Goldstein, 1983). Moreover, heparin induces hepatic release of lipolytic-enzymes to the bloodstream, so the liver contributes with $63 \%$ of the total triacylglycerol lipase (TGL) (Jansen \& Hulsman, 1974). In vitro this liver's lipolytic activity degradates to chylomicrons and in lesser extent to very low density lipoproteins (VLDL) (Krauss et al., 1973). In vivo, the liver removes 20 to $30 \%$ of the triglycerides (TG) contained in the circulating chylomicrons (Bergman et al., 1971). Clearance by the other tissues is carried out by lipoprotein lipase (LPL, E.C. 3.1.1.3.4), enzyme which was considered of extrahepatic origin, but now it has been demonstrated that is present in the liver of a variety of adult animals including sheep (Bergman et al., 1971), fish, chicken and mouse (Reina ct al., 1987), rat (Felts \& Mayes, 1967), dog and man (Condon et al., 1965). It is also

\footnotetext{
This work was supported by a grant from the Research Council of the Universidad Centroccidental "Lisandro Alvarado".

"Corresponding author.

Received 5 October 1992.

Accepted 8 February 1993.
}

found in fetus and newborn animals (Reina et al., 1987). Another lipolytic enzyme, the lipase hepatic $(\mathrm{LH})$, is also liberated from liver by the effect of heparin. LH has different behavior in response to activators and inhibitors of LPL and its function is related with high density lipoprotein (HDL) degradation (Norum et al., 1983).

In hepatosteatosis there is an imbalance in the input and output of liver lipids. In some cases, lipoprotein synthesis in the hepatocyte decreases (Truswell et al., 1969); in others, the fatty acids influx exceeds the liver lipoproteins exporter capacity (Feigelson et al., 1981). Participation of hepatic LPL in the generation of fatty liver is possible because its action provides to hepatocyte the triglyceride-components, these eventually will be deposited in liver tissue. Previously, Fernández et al. (1970) have demonstrated that LPL-activity increases in aortic tissue of rabbits with experimental atherosclerosis and Zilversmit (1973) has indicated that this activity enhancement induces higher offer to arterial wall of cholesterol-rich lipoproteic particles, contributing to tissue lipid deposits.

The cold-acclimatization modified the lipid metabolism. Seller \& You (1952) have observed non liver-triglyceride accumulation in rats submitted to a choline poor diet and main- 
tained at low temperature. In our laboratory, this result was confirmed in cold-acclimatized mice receiving either carbon tetrachloride $\left(\mathrm{CCl}_{4}\right)$ or ethionine (Carmona et al., 1981) two fatty liver inducers. It is unknown the mechanism by which cold protects against $\mathrm{CCl}_{4 \cdot}$ or ethionine-induced hepatosteatosis. Some modifications of lipoprotein lipase activity in tissues of cold-adapted rats have been reported (Radomski \& Orme, 1971). It is possible that the lipotropic effect developed in animals submitted to low temperature, may be related with liver LPL-activity.

The present study was undertaken to measure the activity of hepatic lipoprotein lipase in acclimatized-mice $\left(5^{\circ} \mathrm{C}\right)$ submitted to $\mathrm{CCl}_{4}$ or ethionine, in order to determine the possible role of this enzyme in the fatty liver.

\section{MATERIALS AND METHODS}

Adults albino female mice weighing 25-30 $g$ were housed in individuals cages and allowed free access of water and mouse laboratory pellets (Protinal, Venezuela) and the light on from 7 to 19 hours.

Mice were maintained at either $5 \pm 1{ }^{\circ} \mathrm{C}$ or $27 \pm 2{ }^{\circ} \mathrm{C}$ for three weeks. At the end of this adaptation period the animals were treated with the fatty liver inducer. A group of mice from each temperature $\left(27^{\circ} \mathrm{C}\right.$ and $5^{\circ} \mathrm{C}$ ) received $\mathrm{CCl}_{4}(2 \mathrm{ml} / \mathrm{kg}$ in oil vehicle $)$ by gastric intubation. A group from each temperature was injected i.p. with DL-ethionine $(7.5 \mathrm{mg} / 20 \mathrm{~g}$ in saline solution). In control mice $\left(27^{\circ} \mathrm{C}\right.$ and $5^{\circ} \mathrm{C}$ ) the same volume of vehicle was given. After treatment all animals were fasted for 48 hours at room temperature before sacrifice by decapitation.

The livers were excised and weighed. The amount of total lipids was measured gravimetrically after fat extraction using Folch's method. The results were expressed in $\mathrm{g} / 100 \mathrm{~g}$ of fresh tissue. Samples of each liver were histologically analyzed stained with hematoxilin-eosin and Sudan IV.

Lipoprotein lipase assays - The livers were perfused in situ through the porta vein using a cold Tyrode's solution to wash out any residual blood. The livers were removed, weighed and homogenized in $0.005 \mathrm{M}$ buffer veronal pH 7 for 1 min using an Ultra Turrax (JKIKA-Werk, Staunfen, Germany). The final concentration of tissue homogenates was $10 \%$ w/v. Homogenates were immediately centrifuged for $20 \mathrm{~min}$ at $1000 \mathrm{~g}$ in a refrigerated centrifuge (International Equip. Co., Needham HTS, Mass., USA). All operations were conducted at $4{ }^{\circ} \mathrm{C}$.

Protein determinations in the supernatants were carried out using Kjendahl's method and the activity of lipoprotein lipase was determined by the procedure described by Patten and Hollenberg, but improvement of the incubation medium was done according to Corey \& Zilversmit (1977).

The composition of assay medium was: 2 vol of working substrate and 1 vol of $0.62 \mathrm{M}$ Tris- $\mathrm{HCl}$ buffer $\mathrm{pH}$ 8.6. A fresh working substrate was prepared daily diluting 2 vol of stock substrate with $2 \mathrm{vol}$ of $5 \%(\mathrm{w} / \mathrm{v})$ bovine serum albumin in $0.62 \mathrm{M}$ Tris- $\mathrm{HCl}$ buffer $\mathrm{pH} 8.6$ and $1 \mathrm{vol}$ of rat plasma, previously heated for 60 $\min$ at $56{ }^{\circ} \mathrm{C}$ in order to inactivate some endogenous plasma lipolytic activity.

The stock substrate was prepared homogenizing $553.43 \mathrm{mg}$ of trioleine and $27.07 \mathrm{mg}$ of yolk lecithin in $10 \mathrm{ml}$ of glycerol using an Ultra Turrax.

Assays were carried out by incubating 0.6 $\mathrm{ml}$ of the medium in a shaking water bath (Lab-line Instruments Inc., Melrose Park, Ill, USA) at $30^{\circ} \mathrm{C}$ with $0.4 \mathrm{ml}$ of supernatant tissue homogenate. Tubes were taken out in pairs, after 0 and $1 \mathrm{hr}$. The release of fatty acids was determined according to the microtechnique of Goss \& Lein (1967) using palmitic acid as standard. Control assays without homogenate were performed in order to substract fatty acids release by spontaneous medium's lipolysis. The enzymatic activity was expressed in $\mu \mathrm{Eq}$ of free fatty acids release/ hour per $\mathrm{mg}$ of protein. The results were analyzed using the Student's "t" test.

Chemicals - DL-Ethionine was from $\mathrm{BDH}$ Chemicals Ltd. (Poole, England) and all others chemicals were obtained from Merck (Darmstadt, Germany).

\section{RESULTS}

Large changes were found in the hepatic lipoprotein lipase activity. It was significantly increased in the $27^{\circ} \mathrm{C}$ adapted mice that received $\mathrm{CCl}_{4}$ compared with the control animals (Table I). In this condition was observed 
a liver-lipid content $(15.20 \pm 4.36 \mathrm{~g} \%)$ two fold higher than of the control value $(7.69 \pm$ $1.38 \mathrm{~g} \%)$ and severe histological lesion with extensive necrosis in the centrilobular region and hepatic fatty changes.

\section{TABLE I}

Effect of carbon tetrachloride and ethionine on hepatic lipoprotein lipase activity of acclimatized mice

\begin{tabular}{lc}
\hline $27^{\circ} \mathrm{C}$ adapted mice & $\begin{array}{c}\text { Lipoprotein } \\
\mu \mathrm{Eq} / \mathrm{h} / \mathrm{mg} \text { protein }\end{array}$ \\
A. Control & $0.104 \pm 0.076(7)$ \\
B. With CCl4 & $0.259 \pm 0.060(13)^{a}$ \\
C. With ethionine & $0.219 \pm 0.061(3)^{a}$ \\
$5^{\circ} \mathrm{C}$ adapted mice & \\
D. Control & $0.129 \pm 0.032(6)$ \\
E. With CCl4 & $0.147 \pm 0.030 \quad(8)$ \\
F. With ethionine & $0.157 \pm 0.027(4)$ \\
\hline
\end{tabular}

Values represent the mean $\pm S D$. In parentheses animals number.

$a$ : indicates difference statistically significant with its control $(p<0.01)$.

Ethionine administration also induced a significant enhancement of the liver lipoprotein lipase activity in $27^{\circ} \mathrm{C}$ adapted mice (Table I). As it is usual, these animals presented a markedly increase in the hepatic lipid content $(28.40 \pm 8.58 \mathrm{~g} \%)$ distributed in large cytoplasmic fat droplets in the centrilobular and midzonal area. Necrotic processes were present near of central vein.

Mice acclimatized at $5{ }^{\circ} \mathrm{C}$ did not develop fatty liver neither by $\mathrm{CCl}_{4}$ nor ethionine administration. Liver histology showed absence of fatty infiltration, although mild necrosis was noted in the centrilobular zone. The liver lipid concentration was reduced in both $\mathrm{CCl}_{4}$-fed or ethionine-treated animals maintained at $5{ }^{\circ} \mathrm{C}$ $(6.77 \pm 1.88$ and $5.53 \pm 0.89$, respectively). In both groups, the hepatic lipoprotein lipase activity did not differ of $5^{\circ} \mathrm{C}$ controls values. Furthermore, this controls values were not significantly differents of those found in $27^{\circ} \mathrm{C}$ control mice (Table I).

In this experiment we obscrved that the increased activity of liver-LPL induced by $\mathrm{CCl}_{4}$, presented early onset (Table II). Two hours after treatment, the enzymatic activity was enhanced two fold in comparison to control one. This enhancement remained during the following $48 \mathrm{hr}$.
TABLE II

Effect of the carbon tetrachloride on the hepatic lipoprotein lipase activity of mice kept at laboratory temperature $\left(27 \pm 2{ }^{\circ} \mathrm{C}\right)$

\begin{tabular}{cc}
$\begin{array}{c}\text { Time after treatment } \\
\text { hours }\end{array}$ & $\begin{array}{c}\text { Lipoprotein lipase activity } \\
\mu \mathrm{Eq} / \mathrm{h} / \mathrm{mg} \text { protein }\end{array}$ \\
\hline 0 & $0.104 \pm 0.076(7)$ \\
2 & $0.240 \pm 0.050(3)^{a}$ \\
4 & $0.210 \pm 0.040(3)^{a}$ \\
12 & $0.230 \pm 0.010(3)^{a}$ \\
24 & $0.240 \pm 0.040(3)^{a}$ \\
48 & $0.259 \pm 0.062(13)^{a}$ \\
\hline
\end{tabular}

Each value represents the mean $\pm \mathrm{SD}$. In parentheses number of animals.

$a$ : indicates difference statistically significant with the control $(p<0.01)$.

\section{DISCUSSION}

The existence of LPL activity in the liver is well documented. The enzyme synthesis occurs endogenously in the hepatocyte (Jensen et al., 1980) and its activity is larger in the prenatal phase (Reina et al., 1987). It is possible that in the adult, the enzyme may be in a less active form (Ailhaud, 1990); however, its occurrence in the adult liver has been repeatedly observed in hyperlipemic condition or in pregnant rat submitted to starvation (Vilaró et al., 1990).

The results obtained in this work have indicated that the hepatic-LPL activity was significantly increased in animals maintained to $27^{\circ} \mathrm{C}$ under fatty liver condition (Table I, B and $\mathrm{C}$ groups). This fact is in agreement with previous finding obtained in others tissues. It has been reported in newborn rats that the increase of the triglyceride-adipocyte is in concordance with the enhancement of adipocyte tissue lipoprotein lipase (Ramirez et al., 1983). The other hepatic triacilglycerol lipase (LH) is unaffected in either adult or neonate rat liver under hyperlipemic conditions (Burgaya et al., 1988).

We have determined that the increment of LPL activity had an early onset (Table II), which is in agreement with the rapid hepatic TG-accumulation observed in $\mathrm{CCl}_{4}$-induced fatty liver. It has been reported that the hepatic-TG duplicate their concentration, three hours after ingestion of hepatotoxic (Lombardi, 1965).

The fact that hepatic-LPL activity was increased in fatty liver induced by $\mathrm{CCl} 4$ or ethi- 
onine, it could be indicative that this modification is not specific for a particular fatty liver inducing agent. It may correspond, instead, to a general mechanism by which the high LPL activity could favor the uptake of fatty acids by the liver and their following accumulation as triglycerides. It has been suggested that the LPL activity confers to the liver the capacity of TG-importer (López-Tejero et al., 1988). In others cells, such as macrophages, the predominant mechanism by which the triglycerides are intracellulary accumulated is through the action of lipoprotein lipase (Bates et al., 1984).

In cold-acclimatization, our results had indicated that the LPL activity in the liver was not increased when animals were submitted to hepatoesteatosis inducers (Table I, E and F groups), e.i. mice did not develop fatty liver. In addition, control animals at $5^{\circ} \mathrm{C}$ presented the same enzyme activity that the $27^{\circ} \mathrm{C}$-control (Table I, A and D groups). This fact is in agreement with others authors that had reported no effect of cold exposure on the hepatic-lipoprotein lipase activity in normal rats (Radomski \& Orme, 1971). It is possible that in cold-acclimatization the triglycerides of the blood lipoproteins could be preferentially taken by brown adipose tissue. Chronic exposure to cold induces a constant rise in energetic metabolism.

Based in these results it could be concluded that in the liver of cold-acclimatized mice the enhancement of LPL-activity did not take place by the action of $\mathrm{CCl}_{4}$ or ethionine, as it was observed when animals were kept at room temperature. These agents were unable to induce fatty liver in cold-adapted animals.

\section{REFERENCES}

AILHAUD, G., 1990. Cellular and secreted lipoprotein lipase revisited. Clin. Biochem., 23: 343-347.

BATES, S.; MURPHY, P.; FENG, Z; KANAZAWA, T. \& GETZ, G., 1984. Very density lipoproteins promotes triglyceride accumulation in macrophages. Atherosclerosis, 4: 103-114.

BERGMAN, E.; HAVEL, R.; WOLFE, B. \& BOHMER, T., 1971. Quantitative studies of the metabolism of chylomicron triglycerides and cholesterol by liver and extrahepatic tissues of sheep and dogs. J. Clin. Invest, 50: 1831-1839.

BROWN, M. \& GOLDSTEIN, J., 1983. Lipoprotein receptors in the liver. $J$. Clin. Invest., 2: 743-747.

BURGAYA, F.: LLOBERA, M. \& RAMÍREZ, I., 1988. Acid lipase activity in neonatal rat liver cell types. Effect of starvation. Biochim. Biphys. Acta. 963: 566-569.

CARMONA, C. A.; UBATUBA, F.; RAMIREZ, F. \& MOUSSATCHÉ, H., 1981. Protective action of cold acclimatization against carbon tetrachloride and ethionine-induced fatty liver. Rev. bras. Biol.. 41: 211 213.

CONDON, R.; TOBIAS, H. \& DATTA, D., 1965. The liver and postheparin plasma lipolytic activity in dogs and man. J. Clin. Invest., 44: 860-869.

COREY, J. \& ZILVERSMIT, D., 1977. Validation of a stable emulsion for the assay of lipoprotein lipase activity. J. Lab. Clin. Med., 89: 666-674.

FEIGELSON, E.; PFAFF, W.; KARMER, A. \& STEINBERG, D., 1981. The role of plasma free fatty acids in development of fatty liver. $J$. Clin. Invest., 40: 2171-2179.

FELTS, J. \& MAYES, P. A., 1967. Relcase of lipoprotein lipase from the perfused liver of the rat. $\mathrm{Na}$ ture, 2/4: 620-621.

FERNANDEZ, V.; LÓPEZ, A. \& DOUGLAS, C. R., 1970. Efecto de la dieta aterogénica sobre la actividad lipolitica de la pared arterial. Arch. Biol. Med. Exp., 7: R65.

GOSS, J. \& LEIN, A., 1967. Microtitrination of free fatty acids in plasma. Clin. Chem., 13: 36-39.

JANSEN. H. \& HULSMANN, W., 1974. Liver and extrahepatic contribution to postheparin serum lipase aclivity of the rat. Biochim. Biophys. Acta, 369: 387.396.

JENSEN, G.; BALY, D.; BRANNON, P. \& BENSADOUN, A., 1980. Synthesis and secretion of lipolytic enzymes by culture chicken hepatocytes. $J$. Biol. Chem., 255: 11141-11148.

KRAUSS, R.; WINDMUELLER, H.; LEVI, R. \& FREDRICKSON, D., 1973. Selective measurement of two different triglyceride lipase activities in rat postheparin plasma. J. Lipid Res., 14: 286-294.

LOMBARDI, B., 1965. Pathogenesis of fatty liver. Federation Proc. 24: 1200-1205.

LOPPEZ-TEJERO, D.; LLOBERA. M. \& HERRERA, E., 1988 . High liver lipoprotein lipase activity in hyperlipemic developing rats from undernourished pregnant mothers. Bioscience Rep., 8: 309-314.

NORUM, K.; BERG, T.; HELGERUD, P. \& DREVON, C., 1983. Transport of cholesterol. Physiol. Rev, 63: 1343-1419.

RADOMSKJ, M. \& ORME, T., 1971. Response of lipoprotein lipase in various tissues to cold exposure. Am. J. Physiol., 220: 1852-1856.

RAMÍREZ, I.; LLOBERA, M. \& HERRERA, E., 1983. Circulating triacylglycerols, lipoproteins and tissue lipoprotein lipase activities in rat mothers and offspring during the perinatal period: Effect of postmaturity. Metabolism, 32: 333-341.

REINA, M.; VILARÓ, S.; RAMÍREZ, I. \& LLOBERA, M., 1987. Characterization of lipoprotein lipase activity in the newborn rat liver. Biol. Neonate, 51:4552.

SELLERS, E. \& YOU, R., 19\$2. Effects of cold environment on deposition of fat in the liver in choline deficiency. Biochem. J., 56: 573-576.

TRUSWELL, S.; HANSEN, J.; WATSON, C. \& WANNESBURG, R., 1969. Relation of serum lipids and lipoproteins to fatty liver in Kwashiorkor. J. Clin. Nutr., 22: 563-576.

VILARÓ, S.; TESTAR, X.; RAMfREZ, I. \& LLOBERA, M., 1990. Lipoprotein lipase activity in the liver of starved pregnant rats. Biol. Neonate, 57: 37-40.

ZILVERSMIT, D., 1973. A proposal linking atherogenesis in the interaction of endothelial lipoprotein lipase with triglyceride-rich lipoproteins. Cir. Res., 33: 633-638. 